\title{
Neuropeptide S receptor in GtoPdb v.2021.3
}

\author{
Girolamo Caló ${ }^{1}$, Olivier Civelli ${ }^{2}$, Rainer K. Reinscheid ${ }^{3}$ and Chiara Ruzza ${ }^{4}$
}

1. University of Padova, Italy

2. University of California, Irvine, USA

3. University Hospital Jena, Germany

4. University of Ferrara, Italy

\begin{abstract}
The neuropeptide S receptor (NPS, provisional nomenclature [23]) responds to the 20 amino-acid peptide neuropeptide $\mathrm{S}$ derived from a precursor (NPS, P0C0P6).
\end{abstract}

\section{Contents}

This is a citation summary for Neuropeptide S receptor in the Guide to Pharmacology database (GtoPdb). It exists purely as an adjunct to the database to facilitate the recognition of citations to and from the database by citation analyzers. Readers will almost certainly want to visit the relevant sections of the database which are given here under database links.

GtoPdb is an expert-driven guide to pharmacological targets and the substances that act on them. GtoPdb is a reference work which is most usefully represented as an on-line database. As in any publication this work should be appropriately cited, and the papers it cites should also be recognized. This document provides a citation for the relevant parts of the database, and also provides a reference list for the research cited by those parts. For further details see [6].

Please note that the database version for the citations given in GtoPdb are to the most recent preceding version in which the family or its subfamilies and targets were substantially changed. The links below are to the current version. If you need to consult the cited version, rather than the most recent version, please contact the GtoPdb curators.

\section{Database links}

Neuropeptide S receptor

https://www.guidetopharmacology.org/GRAC/FamilyDisplayForward?familyId=44

Introduction to Neuropeptide $\mathrm{S}$ receptor

https://www.guidetopharmacology.org/GRAC/FamilyIntroductionForward?familyId=44

Receptors

NPS receptor

https://www.guidetopharmacology.org/GRAC/ObjectDisplayForward?objectId=302

\section{References}

1. Acevedo N, Sääf A, Söderhäll C, Melén E, Mandelin J, Pietras CO, Ezer S, Karisola P, Vendelin J and Gennäs GB et al.. (2013) Interaction between retinoid acid receptor-related orphan receptor alpha (RORA) and neuropeptide S receptor 1 (NPSR1) in asthma. PLoS ONE 8: e60111 [PMID:23565190]

2. Adori C, Barde S, Bogdanovic N, Uhlén M, Reinscheid RR, Kovacs GG and Hökfelt T. (2015) Neuropeptide S- and Neuropeptide S receptor-expressing neuron populations in the human pons. Front Neuroanat 9: 126 [PMID:26441556]

3. Beiderbeck DI, Lukas M and Neumann ID. (2014) Anti-aggressive effects of neuropeptide S independent of anxiolysis in male rats. Front Behav Neurosci 8: 185 [PMID:24910598]

4. Bernier V, Stocco R, Bogusky MJ, Joyce JG, Parachoniak C, Grenier K, Arget M, Mathieu MC, O'Neill GP and Slipetz D et al.. (2006) Structure-function relationships in the neuropeptide S receptor: molecular consequences of the asthma-associated mutation N107I. J Biol Chem 281: 
24704-12 [PMID:16790440]

5. Beste C, Konrad C, Uhlmann C, Arolt V, Zwanzger P and Domschke K. (2013) Neuropeptide S receptor (NPSR1) gene variation modulates response inhibition and error monitoring. Neuroimage 71: 1-9 [PMID:23319044]

6. Buneman P, Christie G, Davies JA, Dimitrellou R, Harding SD, Pawson AJ, Sharman JL and Wu Y. (2020) Why data citation isn't working, and what to do about it Database 2020 [PMID:32367113]

7. Bülbül M, Sinen O, Özkan A, Aslan MA and Ağar A. (2019) Central neuropeptide-S treatment improves neurofunctions of 6-OHDA-induced Parkinsonian rats. Exp Neurol 317: 78-86 [PMID:30825442]

8. Camarda V, Rizzi A, Ruzza C, Zucchini S, Marzola G, Marzola E, Guerrini R, Salvadori S, Reinscheid RK and Regoli D et al.. (2009) In vitro and in vivo pharmacological characterization of the neuropeptide s receptor antagonist [D-Cys(tBu)5]neuropeptide S. J Pharmacol Exp Ther 328: 549-55 [PMID:18971372]

9. Cannella N, Economidou D, Kallupi M, Stopponi S, Heilig M, Massi M and Ciccocioppo R. (2009) Persistent increase of alcohol-seeking evoked by neuropeptide S: an effect mediated by the hypothalamic hypocretin system. Neuropsychopharmacology 34: 2125-34 [PMID:19322167]

10. Castro AA, Moretti M, Casagrande TS, Martinello C, Petronilho F, Steckert AV, Guerrini R, Calo' G, Dal Pizzol F and Quevedo J et al.. (2009) Neuropeptide S produces hyperlocomotion and prevents oxidative stress damage in the mouse brain: a comparative study with amphetamine and diazepam. Pharmacol Biochem Behav 91: 636-42 [PMID:19022279]

11. Chauveau F, Claverie D, Lardant E, Varin C, Hardy E, Walter A, Canini F, Rouach N and Rancillac A. (2020) Neuropeptide S promotes wakefulness through the inhibition of sleeppromoting ventrolateral preoptic nucleus neurons. Sleep 43 [PMID:31403694]

12. Clark SD, Duangdao DM, Schulz S, Zhang L, Liu X, Xu YL and Reinscheid RK. (2011) Anatomical characterization of the neuropeptide $\mathrm{S}$ system in the mouse brain by in situ hybridization and immunohistochemistry. J Comp Neurol 519: 1867-93 [PMID:21452235]

13. Clark SD, Kenakin TP, Gertz S, Hassler C, Gay EA, Langston TL, Reinscheid RK and Runyon SP. (2017) Identification of the first biased NPS receptor agonist that retains anxiolytic and memory promoting effects with reduced levels of locomotor stimulation. Neuropharmacology 118: 69-78 [PMID:28267583]

14. D'Amato M, Bruce S, Bresso F, Zucchelli M, Ezer S, Pulkkinen V, Lindgren C, Astegiano M, Rizzetto M and Gionchetti P et al.. (2007) Neuropeptide s receptor 1 gene polymorphism is associated with susceptibility to inflammatory bowel disease. Gastroenterology 133: 808-17 [PMID:17854592]

15. Didonet JJ, Cavalcante JC, Souza Lde S, Costa MS, André E, Soares-Rachetti Vde P, Guerrini R, Calo' G and Gavioli EC. (2014) Neuropeptide S counteracts 6-OHDA-induced motor deficits in mice. Behav Brain Res 266: 29-36 [PMID:24613977]

16. Dine J, Ionescu IA, Avrabos C, Yen YC, Holsboer F, Landgraf R, Schmidt U and Eder M. (2015) Intranasally applied neuropeptide S shifts a high-anxiety electrophysiological endophenotype in the ventral hippocampus towards a "normal"-anxiety one. PLoS ONE 10: e0120272 [PMID:25830625]

17. Domschke K, Reif A, Weber H, Richter J, Hohoff C, Ohrmann P, Pedersen A, Bauer J, Suslow T and Kugel H et al.. (2011) Neuropeptide S receptor gene -- converging evidence for a role in panic disorder. Mol Psychiatry 16: 938-48 [PMID:20603625]

18. Donner J, Haapakoski R, Ezer S, Melén E, Pirkola S, Gratacòs M, Zucchelli M, Anedda F, Johansson LE and Söderhäll C et al.. (2010) Assessment of the neuropeptide S system in anxiety disorders. Biol Psychiatry 68: 474-83 [PMID:20705147]

19. Duangdao DM, Clark SD, Okamura N and Reinscheid RK. (2009) Behavioral phenotyping of neuropeptide S receptor knockout mice. Behav Brain Res 205: 1-9 [PMID:19646487]

20. Erdmann F, Kügler S, Blaesse P, Lange MD, Skryabin BV, Pape HC and Jüngling K. (2015) Neuronal expression of the human neuropeptide S receptor NPSR1 identifies NPS-induced calcium signaling pathways. PLoS ONE 10: e0117319 [PMID:25714705]

21. Fedeli A, Braconi S, Economidou D, Cannella N, Kallupi M, Guerrini R, Calò G, Cifani C, Massi $\mathrm{M}$ and Ciccocioppo R. (2009) The paraventricular nucleus of the hypothalamus is a neuroanatomical substrate for the inhibition of palatable food intake by neuropeptide S. Eur J Neurosci 30: 1594-602 [PMID:19821837]

22. Fendt M, Buchi M, Bürki H, Imobersteg S, Ricoux B, Suply T and Sailer AW. (2011) Neuropeptide $\mathrm{S}$ receptor deficiency modulates spontaneous locomotor activity and the acoustic startle response. Behav Brain Res 217: 1-9 [PMID:20888368]

23. Foord SM, Bonner TI, Neubig RR, Rosser EM, Pin JP, Davenport AP, Spedding M and Harmar AJ. (2005) International Union of Pharmacology. XLVI. G protein-coupled receptor list. Pharmacol Rev 57: 279-88 [PMID:15914470]

24. Gardella E, Romei C, Cavallero A, Trapella C, Fedele E and Raiteri L. (2013) Neuropeptide S inhibits release of 5-HT and glycine in mouse amygdala and frontal/prefrontal cortex through 
activation of the neuropeptide S receptor. Neurochem Int 62: 360-6 [PMID:23411412]

25. Germer J, Kahl E and Fendt M. (2019) Memory generalization after one-trial contextual fear conditioning: Effects of sex and neuropeptide S receptor deficiency. Behav Brain Res 361: 159166 [PMID:30597251]

26. Ghazal P, Corsi M, Roth A, Faggioni F, Corti C, Merlo Pick E, Pucciarelli S, Ciccocioppo R and Ubaldi M. (2014) Paradoxical response to the sedative effects of diazepam and alcohol in C57BL/6J mice lacking the neuropeptide S receptor. Peptides 61: 107-13 [PMID:25240770]

27. Gottlieb DJ, O'Connor GT and Wilk JB. (2007) Genome-wide association of sleep and circadian phenotypes. BMC Med Genet 8 Suppl 1: S9 [PMID:17903308]

28. Guerrini R, Camarda V, Trapella C, Caló G, Rizzi A, Ruzza C, Fiorini S, Marzola E, Reinscheid RK and Regoli D et al.. (2009) Further studies at neuropeptide s position 5: discovery of novel neuropeptide S receptor antagonists. J Med Chem 52: 4068-71 [PMID:19473027]

29. Guerrini R, Salvadori S, Rizzi A, Regoli D and Calo' G. (2010) Neurobiology, pharmacology, and medicinal chemistry of neuropeptide S and its receptor. Med Res Rev 30: 751-77 [PMID:19824051]

30. Gupte J, Cutler G, Chen JL and Tian H. (2004) Elucidation of signaling properties of vasopressin receptor-related receptor 1 by using the chimeric receptor approach. Proc Natl Acad Sci USA 101: 1508-1513 [PMID:14757815]

31. Han RW, Chang M, Peng YL, Qiao LY, Yin XQ, Li W and Wang R. (2009) Central Neuropeptide S inhibits distal colonic transit through activation of central Neuropeptide $\mathrm{S}$ receptor in mice. Peptides 30: 1313-7 [PMID:19540430]

32. Han RW, Xu HJ, Zhang RS, Wang P, Chang M, Peng YL, Deng KY and Wang R. (2014) Neuropeptide S interacts with the basolateral amygdala noradrenergic system in facilitating object recognition memory consolidation. Neurobiol Learn Mem 107: 32-6 [PMID:24211255]

33. Han RW, Yin XQ, Chang M, Peng YL, Li W and Wang R. (2009) Neuropeptide S facilitates spatial memory and mitigates spatial memory impairment induced by N-methyl-D-aspartate receptor antagonist in mice. Neurosci Lett 455: 74-7 [PMID:19429110]

34. Han RW, Zhang RS, Xu HJ, Chang M, Peng YL and Wang R. (2013) Neuropeptide S enhances memory and mitigates memory impairment induced by MK801, scopolamine or $A \beta_{1-42}$ in mice novel object and object location recognition tasks. Neuropharmacology 70: 261-7 [PMID:23454528]

35. Holanda AD, Asth L, Santos AR, Guerrini R, de P Soares-Rachetti V, Calo' G, André E and Gavioli EC. (2015) Central adenosine A1 and A2A receptors mediate the antinociceptive effects of neuropeptide S in the mouse formalin test. Life Sci 120: 8-12 [PMID:25447449]

36. Holanda VAD, Oliveira MC, Souza LS, Lobão-Soares B, André E, Da Silva Junior ED, Guerrini R, Calo G, Ruzza C and Gavioli EC. (2019) Dopamine $D_{1}$ and $D_{2}$ receptors mediate neuropeptide Sinduced antinociception in the mouse formalin test. Eur J Pharmacol 859: 172557 [PMID:31326375]

37. Ionescu IA, Dine J, Yen YC, Buell DR, Herrmann L, Holsboer F, Eder M, Landgraf R and Schmidt U. (2012) Intranasally administered neuropeptide S (NPS) exerts anxiolytic effects following internalization into NPS receptor-expressing neurons. Neuropsychopharmacology 37: 1323-37 [PMID:22278093]

38. Jüngling K, Seidenbecher T, Sosulina L, Lesting J, Sangha S, Clark SD, Okamura N, Duangdao DM, Xu YL and Reinscheid RK et al.. (2008) Neuropeptide S-mediated control of fear expression and extinction: role of intercalated GABAergic neurons in the amygdala. Neuron 59: 298-310 [PMID:18667157]

39. Kallupi M, Cannella N, Economidou D, Ubaldi M, Ruggeri B, Weiss F, Massi M, Marugan J, Heilig M and Bonnavion P et al.. (2010) Neuropeptide S facilitates cue-induced relapse to cocaine seeking through activation of the hypothalamic hypocretin system. Proc Natl Acad Sci USA 107: 19567-72 [PMID:20974945]

40. Kolodziejczyk MH and Fendt M. (2020) Corticosterone Treatment and Incubation Time After Contextual Fear Conditioning Synergistically Induce Fear Memory Generalization in Neuropeptide S Receptor-Deficient Mice. Front Neurosci 14: 128 [PMID:32231512]

41. Kumsta R, Chen FS, Pape HC and Heinrichs M. (2013) Neuropeptide S receptor gene is associated with cortisol responses to social stress in humans. Biol Psychol 93: 304-7 [PMID:23466585]

42. Kushikata T, Yoshida H, Kudo M, Salvadori S, Calo G and Hirota K. (2011) The effects of neuropeptide S on general anesthesia in rats. Anesth Analg 112: 845-9 [PMID:21288975]

43. Laas K, Eensoo D, Paaver M, Lesch KP, Reif A and Harro J. (2015) Further evidence for the association of the NPSR1 gene A/T polymorphism (Asn107lle) with impulsivity and hyperactivity. J Psychopharmacol (Oxford) 29: 878-83 [PMID:25744621]

44. Laas K, Reif A, Kiive E, Domschke K, Lesch KP, Veidebaum T and Harro J. (2014) A functional NPSR1 gene variant and environment shape personality and impulsive action: a longitudinal study. J Psychopharmacol (Oxford) 28: 227-36 [PMID:23325374]

45. Laitinen T, Polvi A, Rydman P, Vendelin J, Pulkkinen V, Salmikangas P, Mäkelä S, Rehn M, 
Pirskanen A and Rautanen A et al.. (2004) Characterization of a common susceptibility locus for asthma-related traits. Science 304: 300-4 [PMID:15073379]

46. Lee MT, Chiu YT, Chiu YC, Hor CC, Lee HJ, Guerrini R, Calo G and Chiou LC. (2020) Neuropeptide S-initiated sequential cascade mediated by $\mathrm{OX}_{1}, \mathrm{NK}_{1}, \mathrm{mGlu}_{5}$ and $\mathrm{CB}_{1}$ receptors: a pivotal role in stress-induced analgesia. J Biomed Sci 27: 7 [PMID:31915019]

47. Lennertz L, Franke PE, Grabe HJ, Rampacher F, Schulze-Rauschenbach S, Guttenthaler V, Ruhrmann S, Pukrop R, Klosterkötter J and Falkai P et al.. (2013) The functional coding variant Asn107Ile of the neuropeptide S receptor gene (NPSR1) influences age at onset of obsessivecompulsive disorder. Int J Neuropsychopharmacol 16: 1951-8 [PMID:23680103]

48. Lennertz L, Quednow BB, Schuhmacher A, Petrovsky N, Frommann I, Schulze-Rauschenbach S, Landsberg MW, Steinbrecher A, Höfels S and Pukrop R et al.. (2012) The functional coding variant Asn107Ile of the neuropeptide S receptor gene (NPSR1) is associated with schizophrenia and modulates verbal memory and the acoustic startle response. Int J Neuropsychopharmacol 15: 1205-15 [PMID:22078257]

49. Leonard SK, Dwyer JM, Sukoff Rizzo SJ, Platt B, Logue SF, Neal SJ, Malberg JE, Beyer CE, Schechter LE and Rosenzweig-Lipson S et al.. (2008) Pharmacology of neuropeptide S in mice: therapeutic relevance to anxiety disorders. Psychopharmacology (Berl.) 197: 601-11 [PMID:18311561]

50. Leonard SK and Ring RH. (2011) Immunohistochemical localization of the neuropeptide S receptor in the rat central nervous system. Neuroscience 172: 153-63 [PMID:20950671]

51. Li W, Chang M, Peng YL, Gao YH, Zhang JN, Han RW and Wang R. (2009) Neuropeptide S produces antinociceptive effects at the supraspinal level in mice. Regul Pept 156: 90-5 [PMID:19345242]

52. Liao Y, Lu B, Ma Q, Wu G, Lai X, Zang J, Shi Y, Liu D, Han F and Zhou N. (2016) Human Neuropeptide S Receptor Is Activated via a Goq Protein-biased Signaling Cascade by a Human Neuropeptide S Analog Lacking the C-terminal 10 Residues. J Biol Chem 291: 7505-16 [PMID:26865629]

53. Liu X, Si W, Garau C, Jüngling K, Pape HC, Schulz S and Reinscheid RK. (2017) Neuropeptide S precursor knockout mice display memory and arousal deficits. Eur J Neurosci 46: 1689-1700 [PMID:28548278]

54. Liu X, Zeng J, Zhou A, Theodorsson E, Fahrenkrug J and Reinscheid RK. (2011) Molecular fingerprint of neuropeptide S-producing neurons in the mouse brain. J Comp Neurol 519: 184766 [PMID:21452230]

55. Lukas M and Neumann ID. (2012) Nasal application of neuropeptide S reduces anxiety and prolongs memory in rats: social versus non-social effects. Neuropharmacology 62: 398-405 [PMID:21871467]

56. Medina G, Ji G, Grégoire S and Neugebauer V. (2014) Nasal application of neuropeptide S inhibits arthritis pain-related behaviors through an action in the amygdala. Mol Pain 10: 32 [PMID:24884567]

57. Meis S, Bergado-Acosta JR, Yanagawa Y, Obata K, Stork O and Munsch T. (2008) Identification of a neuropeptide $\mathrm{S}$ responsive circuitry shaping amygdala activity via the endopiriform nucleus. PLoS ONE 3: e2695 [PMID:18628994]

58. Melamed JY, Zartman AE, Kett NR, Gotter AL, Uebele VN, Reiss DR, Condra CL, Fandozzi C, Lubbers LS and Rowe BA et al.. (2010) Synthesis and evaluation of a new series of Neuropeptide S receptor antagonists. Bioorg Med Chem Lett 20: 4700-3 [PMID:20510609]

59. Okamura N, Garau C, Duangdao DM, Clark SD, Jüngling K, Pape HC and Reinscheid RK. (2011) Neuropeptide S enhances memory during the consolidation phase and interacts with noradrenergic systems in the brain. Neuropsychopharmacology 36: 744-52 [PMID:21150909]

60. Okamura N, Habay SA, Zeng J, Chamberlin AR and Reinscheid RK. (2008) Synthesis and pharmacological in vitro and in vivo profile of 3-oxo-1,1-diphenyl-tetrahydro-oxazolo[3,4a]pyrazine-7-carboxylic acid 4-fluoro-benzylamide (SHA 68), a selective antagonist of the neuropeptide S receptor. J Pharmacol Exp Ther 325: 893-901 [PMID:18337476]

61. Okamura N, Hashimoto K, Iyo M, Shimizu E, Dempfle A, Friedel S and Reinscheid RK. (2007) Gender-specific association of a functional coding polymorphism in the Neuropeptide S receptor gene with panic disorder but not with schizophrenia or attention-deficit/hyperactivity disorder. Prog Neuropsychopharmacol Biol Psychiatry 31: 1444-8 [PMID:17669576]

62. Okazaki Y, Furuno M, Kasukawa T, Adachi J, Bono H, Kondo S, Nikaido I, Osato N, Saito R and Suzuki H et al.. (2002) Analysis of the mouse transcriptome based on functional annotation of 60,770 full-length cDNAs. Nature 420: 563-73 [PMID:12466851]

63. Pañeda C, Huitron-Resendiz S, Frago LM, Chowen JA, Picetti R, de Lecea L and Roberts AJ. (2009) Neuropeptide S reinstates cocaine-seeking behavior and increases locomotor activity through corticotropin-releasing factor receptor 1 in mice. J Neurosci 29: 4155-61 [PMID:19339610]

64. Peng YL, Han RW, Chang M, Zhang L, Zhang RS, Li W, Han YF and Wang R. (2010) Central Neuropeptide $\mathrm{S}$ inhibits food intake in mice through activation of Neuropeptide S receptor. 
Peptides 31: 2259-63 [PMID:20800637]

65. Peng YL, Zhang JN, Chang M, Li W, Han RW and Wang R. (2010) Effects of central neuropeptide $\mathrm{S}$ in the mouse formalin test. Peptides 31: 1878-83 [PMID:20603169]

66. Pulga A, Ruzza C, Rizzi A, Guerrini R and Calo G. (2012) Anxiolytic- and panicolytic-like effects of Neuropeptide S in the mouse elevated T-maze. Eur J Neurosci 36: 3531-7 [PMID:22928868]

67. Pulkkinen V, Ezer S, Sundman L, Hagström J, Remes S, Söderhäll C, Greco D, Dario G, Haglund $\mathrm{C}$ and Kere J et al.. (2014) Neuropeptide S receptor 1 (NPSR1) activates cancer-related pathways and is widely expressed in neuroendocrine tumors. Virchows Arch 465: 173-83 [PMID:24915894]

68. Pulkkinen V, Majuri ML, Wang G, Holopainen P, Obase Y, Vendelin J, Wolff H, Rytilä P, Laitinen LA and Haahtela T et al.. (2006) Neuropeptide S and G protein-coupled receptor 154 modulate macrophage immune responses. Hum Mol Genet 15: 1667-79 [PMID:16600990]

69. Raczka KA, Gartmann N, Mechias ML, Reif A, Büchel C, Deckert J and Kalisch R. (2010) A neuropeptide $S$ receptor variant associated with overinterpretation of fear reactions: a potential neurogenetic basis for catastrophizing. Mol Psychiatry 15: 1045, 1067-74 [PMID:20628342]

70. Raiteri L, Luccini E, Romei C, Salvadori S and Calò G. (2009) Neuropeptide S selectively inhibits the release of 5-HT and noradrenaline from mouse frontal cortex nerve endings. Br J Pharmacol 157: 474-81 [PMID:19371348]

71. Reinscheid RK. (2007) Phylogenetic appearance of neuropeptide S precursor proteins in tetrapods. Peptides 28: 830-7 [PMID:17293003]

72. Reinscheid RK, Xu YL, Okamura N, Zeng J, Chung S, Pai R, Wang Z and Civelli O. (2005) Pharmacological characterization of human and murine neuropeptide s receptor variants. $J$ Pharmacol Exp Ther 315: 1338-45 [PMID:16144971]

73. Ren W, Kiritoshi T, Grégoire S, Ji G, Guerrini R, Calo G and Neugebauer V. (2013) Neuropeptide S: a novel regulator of pain-related amygdala plasticity and behaviors. J Neurophysiol 110: 1765-81 [PMID:23883857]

74. Rizzi A, Vergura R, Marzola G, Ruzza C, Guerrini R, Salvadori S, Regoli D and Calo G. (2008) Neuropeptide $\mathrm{S}$ is a stimulatory anxiolytic agent: a behavioural study in mice. Br J Pharmacol 154: 471-9 [PMID:18376418]

75. Roncacè V, Polli FS, Zojicic M and Kohlmeier KA. (2017) Neuropeptide S (NPS) is a neuropeptide with cellular actions in arousal and anxiety-related nuclei: Functional implications for effects of NPS on wakefulness and mood. Neuropharmacology 126: 292-317 [PMID:28655610]

76. Ruland T, Domschke K, Schütte V, Zavorotnyy M, Kugel H, Notzon S, Vennewald N, Ohrmann P, Arolt V and Pfleiderer B et al.. (2015) Neuropeptide S receptor gene variation modulates anterior cingulate cortex Glx levels during CCK-4 induced panic. Eur Neuropsychopharmacol 25: 1677-82 [PMID:26235955]

77. Ruzza C, Asth L, Guerrini R, Trapella C and Gavioli EC. (2015) Neuropeptide S reduces mouse aggressiveness in the resident/intruder test through selective activation of the neuropeptide $\mathrm{S}$ receptor. Neuropharmacology 97: 1-6 [PMID:25979487]

78. Ruzza C, Ferrari F, Guerrini R, Marzola E, Preti D, Reinscheid RK and Calo G. (2018) Pharmacological profile of the neuropeptide S receptor: Dynamic mass redistribution studies. Pharmacol Res Perspect 6: e00445 [PMID:30534379]

79. Ruzza C, Pulga A, Rizzi A, Marzola G, Guerrini R and Calo' G. (2012) Behavioural phenotypic characterization of CD-1 mice lacking the neuropeptide S receptor. Neuropharmacology 62 : 1999-2009 [PMID:22248636]

80. Ruzza C, Rizzi A, Camarda V, Pulga A, Marzola G, Filaferro M, Novi C, Ruggieri V, Marzola E and Vitale G et al.. (2012) [tBu-D-Gly5]NPS, a pure and potent antagonist of the neuropeptide S receptor: in vitro and in vivo studies. Peptides 34: 404-11 [PMID:22342393]

81. Ruzza C, Rizzi A, Malfacini D, Pulga A, Pacifico S, Salvadori S, Trapella C, Reinscheid RK, Calo $G$ and Guerrini R. (2015) In vitro and in vivo pharmacological characterization of a neuropeptide S tetrabranched derivative. Pharmacol Res Perspect 3: e00108 [PMID:25692025]

82. Ruzza C, Rizzi A, Trapella C, Pela' M, Camarda V, Ruggieri V, Filaferro M, Cifani C, Reinscheid RK and Vitale G et al.. (2010) Further studies on the pharmacological profile of the neuropeptide S receptor antagonist SHA 68. Peptides 31: 915-25 [PMID:20172007]

83. Sartori SB, Maurer V, Murphy C, Schmuckermair C, Muigg P, Neumann ID, Whittle N and Singewald N. (2016) Combined Neuropeptide S and D-Cycloserine Augmentation Prevents the Return of Fear in Extinction-Impaired Rodents: Advantage of Dual versus Single Drug Approaches. Int J Neuropsychopharmacol 19 [PMID:26625894]

84. Sato and Suli et al.. (2002) Novel G protein-coupled receptor protein and DNA thereof. Patent number: WO0231145.

85. Scherer SW, Cheung J, MacDonald JR, Osborne LR, Nakabayashi K, Herbrick JA, Carson AR, Parker-Katiraee L, Skaug J and Khaja R et al.. (2003) Human chromosome 7: DNA sequence and biology. Science 300: 767-72 [PMID:12690205]

86. Shao YF, Wang C, Xie JF, Kong XP, Xin L, Dong CY, Li J, Ren WT and Hou YP. (2016) 
Neuropeptide S ameliorates olfactory spatial memory impairment induced by scopolamine and MK801 through activation of cognate receptor-expressing neurons in the subiculum complex.

Brain Struct Funct 221: 3327-36 [PMID:26323488]

87. Shao YF, Zhao P, Dong CY, Li J, Kong XP, Wang HL, Dai LR and Hou YP. (2013) Neuropeptide S facilitates mice olfactory function through activation of cognate receptor-expressing neurons in the olfactory cortex. PLoS ONE 8: e62089 [PMID:23614017]

88. Sinen O, Bülbül M, Derin N, Ozkan A, Akcay G, Aslan MA and Agar A. (2020) The effect of chronic neuropeptide-S treatment on non-motor parameters in experimental model of Parkinson's disease. Int J Neurosci: 1-10 [PMID:32441169]

89. Smith KL, Patterson M, Dhillo WS, Patel SR, Semjonous NM, Gardiner JV, Ghatei MA and Bloom SR. (2006) Neuropeptide S stimulates the hypothalamo-pituitary-adrenal axis and inhibits food intake. Endocrinology 147: 3510-8 [PMID:16574794]

90. Spada J, Sander C, Burkhardt R, Häntzsch M, Mergl R, Scholz M, Hegerl U and Hensch T. (2014) Genetic association of objective sleep phenotypes with a functional polymorphism in the neuropeptide S receptor gene. PLoS ONE 9: e98789 [PMID:24896296]

91. Tancredi T, Guerrini R, Marzola E, Trapella C, Calo G, Regoli D, Reinscheid RK, Camarda V, Salvadori S and Temussi PA. (2007) Conformation-activity relationship of neuropeptide S and some structural mutants: helicity affects their interaction with the receptor. J Med Chem 50: 4501-8 [PMID:17696420]

92. Tapmeier TT, Rahmioglu N, Lin J, De Leo B, Obendorf M, Raveendran M, Fischer OM, Bafligil C, Guo M and Harris RA et al.. (2021) Neuropeptide S receptor 1 is a nonhormonal treatment target in endometriosis. Sci Transl Med 13 [PMID:34433639]

93. Thorsell A, Tapocik JD, Liu K, Zook M, Bell L, Flanigan M, Patnaik S, Marugan J, Damadzic R and Dehdashti SJ et al.. (2013) A novel brain penetrant NPS receptor antagonist, NCGC00185684, blocks alcohol-induced ERK-phosphorylation in the central amygdala and decreases operant alcohol self-administration in rats. J Neurosci 33: 10132-42 [PMID:23761908]

94. Tillmann S, Skibdal HE, Christiansen SH, Gøtzsche CR, Hassan M, Mathé AA, Wegener G and Woldbye DPD. (2019) Sustained overexpression of neuropeptide $S$ in the amygdala reduces anxiety-like behavior in rats. Behav Brain Res 367: 28-34 [PMID:30914309]

95. Trotter BW, Nanda KK, Manley PJ, Uebele VN, Condra CL, Gotter AL, Menzel K, Henault M, Stocco R and Renger JJ et al.. (2010) Tricyclic imidazole antagonists of the Neuropeptide S Receptor. Bioorg Med Chem Lett 20: 4704-8 [PMID:20615693]

96. Vendelin J, Pulkkinen V, Rehn M, Pirskanen A, Räisänen-Sokolowski A, Laitinen A, Laitinen LA, Kere J and Laitinen T. (2005) Characterization of GPRA, a novel G protein-coupled receptor related to asthma. Am J Respir Cell Mol Biol 33: 262-70 [PMID:15947423]

97. Vitale G, Filaferro M, Ruggieri V, Pennella S, Frigeri C, Rizzi A, Guerrini R and Calò G. (2008) Anxiolytic-like effect of neuropeptide $S$ in the rat defensive burying. Peptides 29: 2286-91 [PMID:18793688]

98. Wan Saudi WS, Halim MA, Rudholm-Feldreich T, Gillberg L, Rosenqvist E, Tengholm A, Sundbom M, Karlbom U, Näslund E and Webb DL et al.. (2015) Neuropeptide S inhibits gastrointestinal motility and increases mucosal permeability through nitric oxide. Am J Physiol Gastrointest Liver Physiol 309: G625-34 [PMID:26206857]

99. Xing L, Shi G, Mostovoy Y, Gentry NW, Fan Z, McMahon TB, Kwok PY, Jones CR, Ptáček LJ and Fu YH. (2019) Mutant neuropeptide $S$ receptor reduces sleep duration with preserved memory consolidation. Sci Transl Med 11 [PMID:31619542]

100. Xu YL, Gall CM, Jackson VR, Civelli O and Reinscheid RK. (2007) Distribution of neuropeptide S receptor mRNA and neurochemical characteristics of neuropeptide S-expressing neurons in the rat brain. J Comp Neurol 500: 84-102 [PMID:17099900]

101. Xu YL, Reinscheid RK, Huitron-Resendiz S, Clark SD, Wang Z, Lin SH, Brucher FA, Zeng J, Ly NK and Henriksen SJ et al.. (2004) Neuropeptide S: a neuropeptide promoting arousal and anxiolytic-like effects. Neuron 43: 487-97 [PMID:15312648]

102. Zhang S, Jin X, You Z, Wang S, Lim G, Yang J, McCabe M, Li N, Marota J and Chen L et al.. (2014) Persistent nociception induces anxiety-like behavior in rodents: role of endogenous neuropeptide S. Pain 155: 1504-15 [PMID:24793908]

103. Zhang Y, Gilmour BP, Navarro HA and Runyon SP. (2008) Identifying structural features on 1,1diphenyl-hexahydro-oxazolo[3,4-a]pyrazin-3-ones critical for Neuropeptide S antagonist activity. Bioorg Med Chem Lett 18: 4064-7 [PMID:18555684]

104. Zhao P, Qian X, Nie Y, Sun N, Wang Z, Wu J, Wei C, Ma R, Wang Z and Chai G et al.. (2019) Neuropeptide $S$ Ameliorates Cognitive Impairment of APP/PS1 Transgenic Mice by Promoting Synaptic Plasticity and Reducing A $\beta$ Deposition. Front Behav Neurosci 13: 138 [PMID:31293402]

105. Zhu H, Mingler MK, McBride ML, Murphy AJ, Valenzuela DM, Yancopoulos GD, Williams MT, Vorhees CV and Rothenberg ME. (2010) Abnormal response to stress and impaired NPS-induced hyperlocomotion, anxiolytic effect and corticosterone increase in mice lacking NPSR1.

Psychoneuroendocrinology 35: 1119-32 [PMID:20171785] 
